\title{
UJI EFEK TONIKUM EKSTRAK ETANOL DAUN SAMBILOTO (Andrographis paniculata, Nees.) TERHADAP MENCIT JANTAN (Mus musculus L.) GALUR SWISS
}

\author{
Susi Endrawati, Feni Indriyani \\ Program Studi DIII Farmasi Poltekkes Bhakti Mulia Sukoharjo \\ Email: susiendrawati5@gmail.com
}

\begin{abstract}
Background: The tonic is a substance that can improve our body strength. It can recover the staff our body shortly. It can also make our body stronger and can stimulates our appetite.

Objective: Knowing the most effective tonic effect dose variation among ethanol extract of bitter leaf on male mice (Mus musculus L.) Swiss Strain.

Methods: This study is an experimental research design with True experimental design approach Posttest Pretest with control group. The ethanol extract of bitter leaf is made with bitter leaf quote using ethanol $96 \%$ with maceration method. The provision of treatment in test animals distinguished on several variations of dosage. In preparation extracts there are 5 groups, namely: group I, II, III, IV, V treated positive control caffeine $13 \mathrm{mg} / \mathrm{kg}$, cooking oil as a negative control, the ethanol extract at a dose of $50 \mathrm{mg} / \mathrm{kg}, 100 \mathrm{mg} / \mathrm{kg}, 200 \mathrm{mg} / \mathrm{kg}$. Data obtained tonic effect of added time the mice's ability to defend itself when direnangkan. Data were analyzed by ANOVA using SPSS 18.0 for windows followed by a test post hoc test and ED50 probit analysis to determine the most effective dose as a tonic.

Result: Ethanol extract of bitter leaf at a dose of $50 \mathrm{mg} / \mathrm{kg}$ have a tonic effect of 9.2 minutes, a dose of $100 \mathrm{mg} / \mathrm{kg}$ have a tonic effect of 13.4 minutes, and a dose of $200 \mathrm{mg} / \mathrm{kg}$ have a tonic effect 23 minutes. Results yield of ethanol extract of bitter leaf maceration $7.8 \% \mathrm{~b} / \mathrm{b}$.

Conclusion: The ethanol extract of bitter leaf tested in test animals male mice (Mus muculus L.) at all doses provide a tonic effect, and the effect will increase along with increasing doses of test substance preparation.
\end{abstract}

Key Words: Tonic effect, Extract, Sambiloto (Andrographis paniculata, Nees.,), Male mice (Mus musculus L.)

\section{PENDAHULUAN}

Indonesia memiliki 3000 jenis tanaman obat namun baru sekitar 450 saja yang sudah diketahui khasiatnya sehingga perkembangan obat di Indonesia belum pesat. Obat tradisional belum bisa diterima sepenuhnya oleh kalangan medis dan dunia kedokteran modern. Namun akhir - akhir ini penelitian mengenai obat tradisional semakin banyak dilakukan baik oleh kalangan akademis, medis maupun instansi swata dan pemerintah (Prapanza dan Marianto, 2003: 1). Penggunaan obat penambah stamina pada zaman sekarang ini semakin meluas. Hal ini seiring dengan kebutuhan masyarakat yang semakin meningkat pola aktivitas kerjanya. Masyarakat pada era ini membutuhkan kerja ekstra keras karena semakin banyaknya tuntutan atau persaingan untuk memenuhi kebutuhan sosial dan ekonomi. Masyarakat yang dituntut bekerja ekstra keras akan membutuhkan tenaga ekstra. Obat penambah stamina dibutuhkan untuk meningkatkan stamina.
Tonikum merupakan zat yang dapat meningkatkan stamina untuk memulihkan tenaga dalam waktu singkat. Tonikum adalah obat yang menguatkan badan dan merangsang selera makan. Tonikum adalah istilah yang dahulu digunakan untuk kelas preparat obat obatan yang dipercaya mempunyai kemampuan mengembalikan tonus normal pada jaringan. Tonikum mempunyai efek yang menghasilkan tonus normal yang ditandai dengan ketegangan terus - menerus (Mutschler, 1986: 157).

Salah satu tanaman yang dapat digunakan sebagai obat yaitu tanaman sambiloto (Andrographis paniculata, Nees.). Tanaman ini mengandung bahan kimia diantaranya senyawa andrographolid yang menyebabkan rasa pahit terutama bagian daun dan batangnya. Senyawa ini merupakan bahan aktif daun sambiloto (Andrographis paniculata, Nees.) yang banyak mengandung unsur - unsur mineral seperti kalium, natrium, kalsium dan asam kersik. (Prapanza dan Marianto, 2003: 9). 
Penelitian yang sudah dilakukan oleh Warditiani menunjukkan bahwa ekstrak etanol terpurifikasi herba sambiloto (Andrographis paniculata, Nees.) positif mengandung golongan flavonoid dan terpenoid dimana senyawa tersebut diduga dapat menimbulkan efek tonikum. Selain daun, bagian lain dari sambiloto juga berguna, V.Ravi et all dari India melakukan penelitian bunga sambiloto yang diekstraksi dengan metanol untuk menghambat pertumbuhan bakteri, dengan mengukur diameter zona penghambat.

Daun sambiloto (Andrographis paniculata, Nees.) juga mempunyai khasiat sebagai antioksidan, antidiabetes dan obat tifus. Berdasarkan penelitian Yellita (2011) bahwa ekstrak methanol daun sambiloto dapat digunakan sebagai antioksidan, secara biologis antioksidan adalah senyawa yang mampu menangkal atau meredam dampak negatif oksidan dalam tubuh. Keseimbangan oksidan dan antioksidan sangat penting karena berkaitan dengan berfungsinya sistem imunitas tubuh, penelitian tersebut relevan dan dikuatkan oleh penelitian Shirisha, K and Mastan, M (2013) dari india.

Banyaknya manfaat daun sambiloto tersebut dan pentingnya masyarakat untuk mengetahui, manfaat herbal obat tradisional, menjadi dasar dalam latar belakang penelitian ini apakah ekstrak etanol daun sambiloto (Andrographis paniculata, Nees.) mempunyai efek tonik pada mencit.

Tujuan penelitian ini adalah Mengetahui efek tonikum paling efektif diantara variasi dosis ekstrak etanol daun sambiloto pada mencit jantan (Mus musculus L.) Galur Swiss. Adapun manfaat penelitian ini yaitu untuk memperoleh data ilmiah mengenai khasiat daun sambiloto yang mempunyai efek tonik dan dapat dimanfaatkan oleh masyarakat dan sebagai tambahan pengetahuan untuk pengembangan serta pemanfaatan daun sambiloto dalam bidang farmasi.

\section{METODOLOGI PENELITIAN}

Penelitian ini eksperimental dilakukan di Laboratorium Farmakognosi dan Farmakologi
Prodi DIII Farmasi Politeknik Kesehatan Bhakti Mulia Sukoharjo untuk mengetahui efek tonikum ekstrak etanol dan infusa daun Sambiloto (Andrographis paniculata, Nees.) terhadap hewan uji mencit galur swiss. Sampel dari penelitian ini adalah daun sambiloto yang diambil di wilayah kabupaten Pacitan, Jawa Timur dan mencit jantan galur swiss. Pengolahan daun sambiloto dilakukan dengan cara daun yang berwarna hijau dicuci bersih, ditiriskan, dipotong kecil-kecil kemudian dikeringkan dalam oven lalu dibuat ekstrak dengan metode maserasi.

Alat yang digunakan yaitu batang pengaduk, gelas ukur, cawan penguap, pipet tetes, kain flanel, kertas saring, beker glass, spuit peroral, handuk pengering, timbangan analitik, blender, waterbath, stopwatch dan bejana air. Bahan yang digunakan yaitu simplisian daun sambiloto, etanol 96\%, minyak goreng, kafein dan hewan uji mencit.

Prosedur dalam penelitian ini adalah sebagai berikut:

1. Pembuatan Ekstrak Etanol Daun Sambiloto dengan metode Maserasi

Daun sambiloto 100 gram dimasukkan ke dalam wadah maserasi, ditambahkan etanol $96 \%$ sebanyak $750 \mathrm{ml}$ hingga terendam sempurna. Didiamkan selama 18 jam aduk sesekali selama 6 jam. Didiamkan lagi selama 18 jam. Kemudian disaring menggunakan kain flanel dan ampasnya dibilas dengan sisa etanol sebanyak $250 \mathrm{ml}$. Ekstrak etanol yang diperoleh diuapkan diatas waterbath hingga diperoleh ekstrak kental. (Dirjen POM,1986:11).

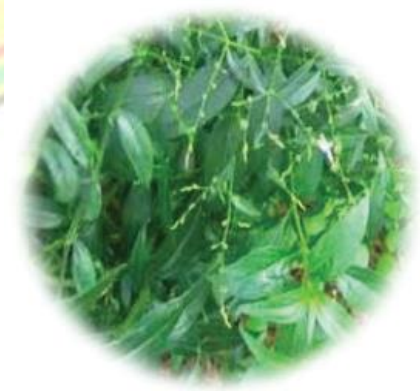

Gambar 1. Daun Sambiloto

2. Pembuatan larutan kafein dosis $13 \mathrm{mg} / \mathrm{kg}$ BB dibuat dengan menimbang kafein sebanyak $13 \mathrm{mg}$ kemudian dilarutkan dengan minyak goreng sebanyak $25 \mathrm{ml}$. 
Dosis ekstrak etanol daun sambiloto 50 $\mathrm{mg} / \mathrm{kgBB}$ dibuat dengan menimbang ekstrak $50 \mathrm{mg}$ dilarutkan dengan minyak goreng sampai $25 \mathrm{ml}$. Dosis ekstrak etanol daun sambiloto $100 \mathrm{mg} / \mathrm{kgBB}$ dibuat dengan menimbang ekstrak sebanyak $100 \mathrm{mg}$ kemudian dilarutkan dengan minyak goreng sampai $25 \mathrm{ml}$. Dosis ekstrak etanol daun sambiloto $200 \mathrm{mg} / \mathrm{kgBB}$ dibuat dengan menimbang ekstrak sebanyak $200 \mathrm{mg}$ kemudian dilarutkan dengan minyak goreng sampai $25 \mathrm{ml}$.
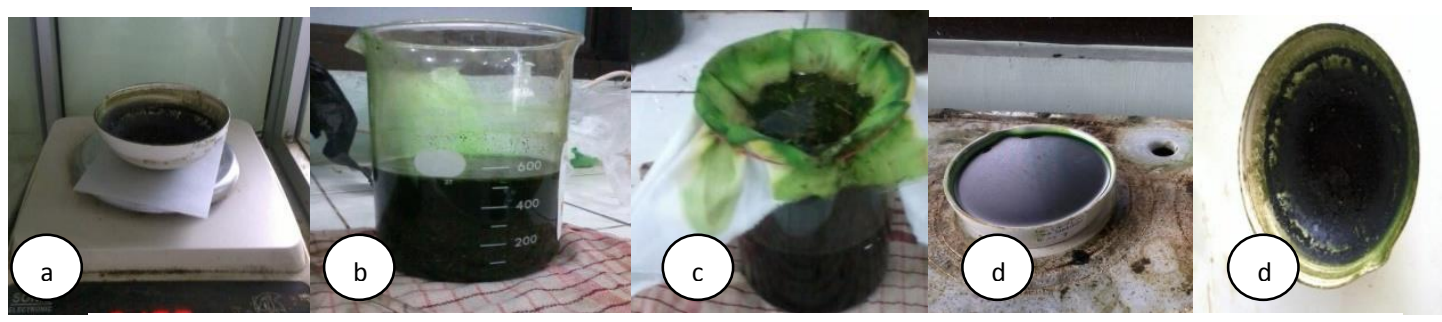

Gambar 2. Proses a. penimbangan, b. maserasi, c. penyaringan, d.penguapan, e.hasil maserasi

3. Pemilihan dan penyiapan hewan uji

Hewan uji yang digunakan adalah mencit jantang galur swiss yang berumur 1-2 bulan dengan berat badan 20 - 30 gram. Diadaptasi dengan lingkungan sekitar selama satu minggu.

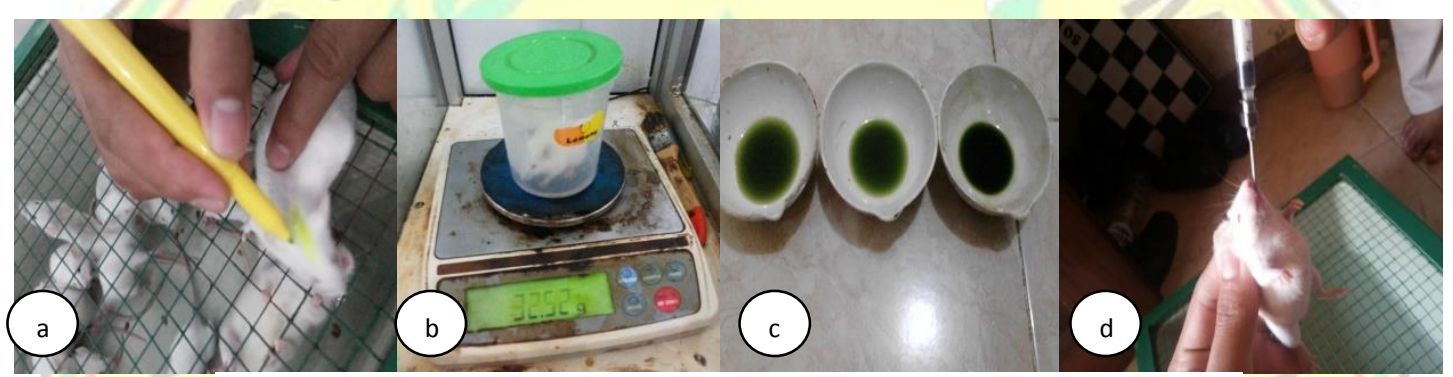

Gambar 3. a.penandaan, b. penimbangan, c. ekstrak, d. perlakuan peroral

\section{Perlakuan Hewan Uji Mencit}

Hewan uji dipuasakan selama 8 jam sebelum diuji cobakan. Hewan uji berjumlah 25 ekor mencit terbagi dalam 5 kelompok, masingmasing terdiri dari 5 ekor mencit. Kelompok I kontrol positif, kelompok II kontrol negative, III, IV, V perlakuan secara peroral ekstrak etanol daun sambiloto, dosis $50 \mathrm{mg} / \mathrm{kg} \mathrm{BB}$, dosis 100 $\mathrm{mg} / \mathrm{kg} \mathrm{BB}$, dan dosis $200 \mathrm{mg} / \mathrm{kg}$ BB. Perlakuan hewan uji mencit dengan menggunakan metode ketahanan berenang. Aktivitas motorik diuji dengan cara mencit dimasukkan kedalam wadah yang berisi air, 30 menit setelah pemberian sediaan. Ketahanan berenang diukur berdasarkan waktu mencit mulai berenang sampai tenggelam, yaitu mencit berada dibawah permukaan air selama 7 detik. Data yang diperoleh dari hasil pengamatan yaitu dengan mencatat waktu timbul kelelahan dari masing - masing perlakuan. Data yang diperoleh dianalisis dengan uji ANOVA menggunakan SPSS 18.0 for windows dilankutkan dengan uji post hoc test dan analisa probit $\mathrm{ED}_{50}$ untuk menentukan dosis yang paling efektif sebagai tonikum.

\section{HASIL DAN PEMBAHASAN}

Pelarut yang digunakan dalam pembuatan ekstrak adalah etanol $96 \%$, karena etanol 96\% mempunyai tingkat kepolaran semipolar. Terpenoid diduga zat yang menyebabkan tonikum memiliki tingkat kepolaran semipolar, sehingga dapat larut dalam etanol $96 \%$. Penelitian daun sambiloto ini menghasilkan efek tonik yang baik. Pada simplisia daun sambiloto sebanyak $100 \mathrm{mg}$ yang dimaserasi dengan etanol 96\% sebanyak $1000 \mathrm{ml}$ diperoleh ekstrak kental sebanyak 7,80 gram, rendemen yang diperoleh adalah $7,8 \%$. Penelitian relevan juga dilakukan oleh Warditiani (2012) yang menghasilkan ektrak terpurifikasi dari herba sambiloto 
(Andrographis paniculata, Nees.). Ekstrak positif mengandung golongan senyawa flavonoid dan terpenoid, hanya bedanya ekstrak terpurifikasi dibuat dengan mengekstraksi serbuk herba sambiloto (Andrographis paniculata, Nees.) dengan metode maserasi menggunakan etanol $90 \%$, kemudian dilakukan purifikasi bertahap menggunakan pelarut $\mathrm{n}$ heksan. Senyawa terpenoid merupakan golongan stimulan. Alasan Ekstrak etanol digunakan yaitu, lebih selektif, kapang dan kuman sulit tumbuh dalam etanol $20 \%$ keatas, tidak beracun, netral, absorbsinya baik, etanol dapat bercampur dengan air pada segala perbandingan, panas yang diperlukan untuk pemekatan sedikit. Selain itu zat aktif yang berefek sebagai stimulant yaitu flavonoid dan terpenoid larut dalam etanol.

Berbeda halnya dengan penelitian uji tonikum biji cola yang dilakukan oleh Wahyuni (2008), penarikan ekstrak dilakukan dengan cara infudasi karena alkaloid golongan xantin yang terkandung pada biji cola dapat larut dalam air, meskipun tidak dapat larut sempurna. Hal tersebut menyebabkan efek tonik yang ditimbulkan rendah.

Tabel 1. Hasil Pengamatan Lama Waktu Bertahan yang Digunakan oleh Mencit Setelah Pemberian Ekstrak Etanol

\begin{tabular}{cccccc}
\multicolumn{5}{c}{ Daun Sambiloto dengan Metode Ketahanan Berenang } \\
\hline \multirow{2}{*}{ Replikasi } & $\begin{array}{c}\text { Kontrol } \\
\text { Positif } \\
\text { (menit) }\end{array}$ & $\begin{array}{c}\text { Kontrol } \\
\text { Negatif } \\
\text { (menit) }\end{array}$ & $\begin{array}{c}\text { Ekstrak Dosis 50 } \\
\text { mg } \\
\text { (menit) }\end{array}$ & $\begin{array}{c}\text { Ekstrak Dosis } \\
100 \text { mg (menit) }\end{array}$ & $\begin{array}{c}\text { Ekstrak Dosis } \\
200 \text { mg (menit) }\end{array}$ \\
\hline I & 22 & 1 & 7 & 13 & 24 \\
II & 12 & 2 & 9 & 12 & 23 \\
III & 24 & 1 & 11 & 15 & 22 \\
IV & 20 & 1 & 10 & 14 & 23 \\
V & 19 & 3 & 9,2 & 13,4 & 23 \\
\hline Rata - rata & 19,4 & 1,6 & & & 23 \\
\hline
\end{tabular}
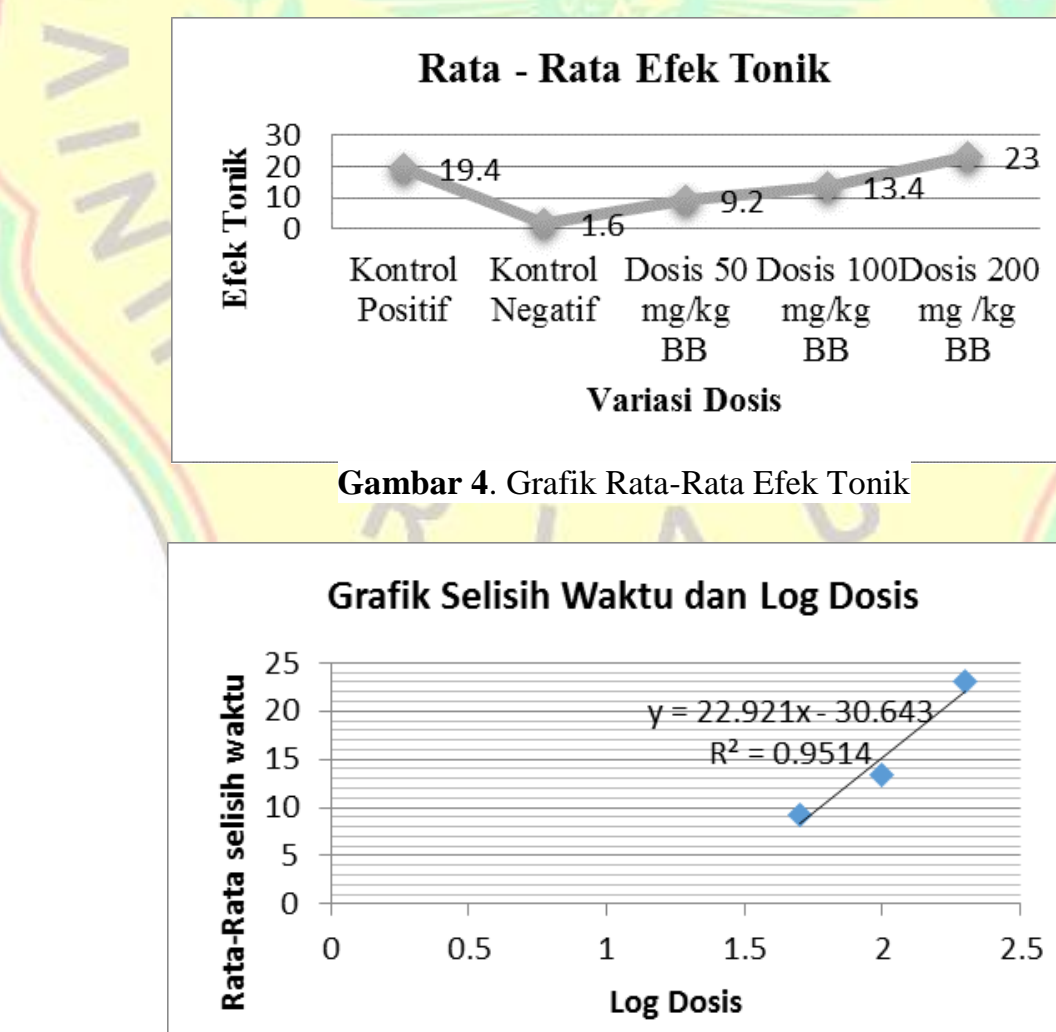

Gambar 5. Grafik Selisih Waktu dan Log dosis 
Hasil analisis uji One Way Anova yang diperoleh menunjukkan nilai $\alpha>$ Sig, dimana nilai $\alpha=0,05$ dan nilai Sig. $=0.0001$ maka $\mathrm{H}_{0}$ ditolak, jadi kesimpulannya ada perbedaan signifikan daya tonikum ekstrak etanol daun sambiloto pada mencit jantan. Kemudian dilanjutkan dengan analisis Post Hoc Test untuk mengetahui secara rinci apakah ada perbedaan yang bermakna antar kelompok perlakuan dengan uji LSD. Hasil uji lanjutan dengan analisis Post Hoc Test, pada pengamatan lama waktu mencit berenang menunjukkan bahwa terdapat perbedaan efek yang signifikan atau ada perbedaan efek yang bermakna antara kelompok kontrol dan kelompok perlakuan ekstrak etanol daun sambiloto dosis $50 \mathrm{mg} / \mathrm{kg} \mathrm{BB}, 100 \mathrm{mg} / \mathrm{kg}$ BB dan $200 \mathrm{mg} / \mathrm{kg}$ BB. Pemberian ekstrak etanol daun sambiloto dosis $50 \mathrm{mg} / \mathrm{kg}$ BB menunjukkan efek tonikum yang lebih pendek pada mencit dengan menggunakan ketahanan berenang rata - rata 9,2 menit, ekstrak etanol daun sambiloto dosis $100 \mathrm{mg} / \mathrm{kg} \quad \mathrm{BB}$ menunjukkan efek tonikum pada mencit menggunakan ketahanan berenang rata - rata 13,4 menit dan pemberian ekstrak etanol daun sambiloto dosis $200 \mathrm{mg} / \mathrm{kg}$ BB menunjukkan efek tonikum yang paling tinggi pada mencit menggunakan ketahanan berenang rata - rata 23 menit, untuk pemberian minyak goreng sebagai kontrol negatif menunjukkan lama waktu ketahanan berenang yang sangat pendek yaitu rata - rata sebesar 1,6 menit, sedangkan pemberian kafein $13 \mathrm{mg} / \mathrm{kg} \mathrm{BB}$ rata - rata sebesar 19,4 menit. Hal ini menunjukkan bahwa dosis $200 \mathrm{mg} / \mathrm{kg}$ BB ekstrak etanol daun sambiloto dapat memberikan efek tonikum lebih lama.

Data efek tonik dari setiap dosis uji efektifitas dianalisis menggunakan analisa Probit dan diperoleh $\mathrm{ED}_{50}$ dari ekstrak etanol daun sambiloto sebesar 74,554 mg/kg BB. Hal ini menunjukkan bahwa pada dosis ekstrak etanol daun sambiloto $74,554 \mathrm{mg} / \mathrm{kg} \quad \mathrm{BB}$ senyawa aktif yang terkandung dalam ekstrak etanol daun sambiloto mampu memberikan 50\% efek tonikum pada hewan uji mencit.

Manfaat daun sambiloto yang banyak juga dikuatkan pleh penelitian yang dilakukan oleh
Yulinah (2001) bahwa ekstrak etanol herba sambiloto (Andrographis paniculata, Nees.) mempunyai efek menurunkan glukosa darah pada uji toleransi glukosa dengan efek yang meningkat dengan peningkatan dosis pada kisar dosis yang diberikan $0,5-2,0 \mathrm{~g} / \mathrm{kg}$ BB. Perbedaan penelitian ini dengan penelitian Yulinah (2001) yaitu uji toleransi glukosa pada tikus dan mencit diabetes yang diinduksi dengan aloksan, sedangkan pada penelitian ini ekstrak etanol daun sambiloto (Andrographis paniculata, Nees.) pada kisar dosis $50-200$ $\mathrm{mg} / \mathrm{kg}$ BB dapat memberikan efek tonikum dengan metode ketahanan tubuh yaitu dengan cara mencit direnangkan setelah diberi ekstrak. Jadi, pada dosis rendah ekstrak etanol daun sambiloto memiliki efek tonikum dan pada dosis tinggi ekstrak etanol daun sambiloto dapat menurunkan glukosa darah.

Hasil penelitian dapat disimpulkan bahwa semakin tinggi konsentrasi ekstrak etanol daun sambiloto semakin lama ketahanan berenang mencit. Hal ini kemungkinan dapat disebabkan oleh efek tonik dari ekstrak etanol daun sambiloto yang terjadi karena efek stimulan yang dilakukan terhadap sistem saraf pusat sehingga dapat menambah gairah atau stamina mencit. Hal ini sesuai dengan teori yang dikemukakan Gunawan (2006) bahwa tonikum adalah zat yang digunakan untuk mengembalikan kondisi normal jaringan atau untuk merangsang nafsu makan. Sehingga dapat mengembalikan tenaga yang hilang, memulihkan stamina, melancarkan peredaran darah, menambah gairah dan menjaga berat badan.

\section{KESIMPULAN DAN SARAN}

\section{Kesimpulan}

Hasil penelitian disimpulkan bahwa ekstrak etanol daun sambiloto (Andrograpolis panicullata, Ness) pada dosis $50 \mathrm{mg} / \mathrm{kg} \mathrm{BB}, 100$ $\mathrm{mg} / \mathrm{kg}$ BB dan $200 \mathrm{mg} / \mathrm{kg}$ BB dengan metode ketahanan berenang menunjukkan efek tonikum pada mencit, dan memberikan efek tonik yang efektif berdasarkan analisa probit dengan uji $\mathrm{ED}_{50}$ adalah pada dosis $74,554 \mathrm{mg} / \mathrm{kg}$ BB. 


\section{Saran}

Penelitian lebih lanjut kandungan kimia atau khasiat yang terdapat dalam ekstrak etanol daun sambiloto (Andrograpolis panicullata, Ness) yang dapat memberikan efek tonik pada hewan uji menggunakan metode Kromatografi Lapis Tipis atau membandingkan efek tonik sediaan ekstrak etanol dan infusa daun sambiloto sebagai efek tonikum.

\section{DAFTAR PUSTAKA}

Dirjen POM. 1986. Sediaan Galenik. Jakarta: Departemen Kesehatan Republik Indonesia

Gunawan, Didik, 2006, Resep - resep Ramuan Tradisional untuk Keharmonisan Suami Istri,

Mutschler, E. 1986. Dinamika Obat, diterjemahkan oleh Widianto, MB, dan Ranti, AS Edisi Kelima. Bandung: Penerbit ITB

Prapanza, I, dan Marianto LA. 2003. Khasiat dan Manfaat Sambiloto. Jakarta: Agromedia Pustaka

Shirisha, K and Mastan,M. 2013. Andrographis Paniculata and its Bioactive Phytochemical Constituents For oxidative
Damage: Asystemic review. Journal Pharmacophore USA Coden. Pharm 7. ISSN 2229-5402 Vol 4(6), 212-229.

Wahyuni, SA, dan Kusumawati, F. 2008. Efek Tonik Ekstrak Air Biji Cola (Cola nitida Schott \& Endl) pada Mencit Jantan. Jurnal Penelitian Sains \& Teknologi Vol. 9 (2): $137-143$

Warditiani, NK, Larasanty, LPF, Widjaja, LNK, Juniari, NPM, Nugroho, AE, Pramono, S. 2012. Identifikasi Kandungan Kimia Ekstrak Terpurifikasi Herba Sambiloto.

Jurnal Farmasi Universitas Udayana: $22-25$

Yellita Y, Cahyaningsih U, Pradono DI, Winarsih W, Manalu W.2011. Ekstrak Sambiloto Menurunkan Patogenesis Ookista Eimeria TenellaI. Jurnal Veteriner Vol 12 (4): 307-318

Yulinah E, Sukrasno dan Muna AF. 2001. Aktivitas Antidiabetika Ekstrak Etanol Herba Sambiloto (Andrographis panicullata Nees (Acanthaceae)). Jurnal Farmasi FMIPA ITB Vol 6 (1): 13 - 20

V. Ravi et al. Antimicrobial Activity of Andrographis Paniculata Flower Extracts. Journal IJRRPAS, 2(3) 604-610, ISSN: 2249-1236. 